Running head: RELIGIOUS PROSOCIALITY

\title{
Religious Prosociality: Personal, Cognitive, and Social Factors
}

\author{
Jesse Lee Preston, Erika Salomon, and Ryan S. Ritter
}

University of Illinois at Urbana-Champaign

Chapter in preparation for: Religion, personality, and social behavior. V. Saroglou (Ed.) 


\section{Religious Prosociality: Personal, Cognitive, and Social Factors}

Morality, and the instruction for moral behavior, is a central theme in religion. All major world religions explicitly teach prosociality as a virtue, and share some version of the Golden rule-treat others as you would want to be treated (e.g., parable of the Good Samaritan, Luke 10: 25-37, King James Version; Baha''u'lla'h calling on his followers to 'desire not for anyone the things you would not desire for yourselves,' Gleanings from the Writings of Baha' 'u'lla 'h, LXVI, Effendi, 1976; or Lao-Tzu's description of 'true goodness', Tao-Te Ching; Mitchell, 2006). What's more, stories of gods in all religions and cultures suggest they are concerned with human morality and willing to punish or reward accordingly (Roes \& Raymond 2003; Shariff, Norenzayan, \& Henrich, 2007). Given the close association between religious beliefs and moral issues, many argue that religion promotes prosociality and facilitates cooperation in large societies. But what are the true effects of religion on prosociality? The psychological literature reveals a complex relation between religious belief and moral action, leading to greater prosocial behavior in some contexts but not in others.

In this chapter, we provide an updated review of research and theory on religious prosociality. Prosociality is defined here as helping behavior-that is, providing some personal assistance to a target, whether through direct actions or more indirect means such as donations, or volunteer work. This narrow definition excludes other behaviors generally related to morality but not specifically to helping, for example, cheating and dishonesty (Randolph-Seng \& Nielsen, 2007; Shariff \& Norenzayan, 2011), or prejudice (Allport \& Ross, 1967; Johnson \& Rowatt, 2010). In addition, we do not focus here on antisocial behavior (harming others), which also has its own important associations with religion (Ginges, Hansen, \& Norenzayan, 2009; Bushman et al., 2007). 
Some excellent reviews on religion and prosociality have been written, and offer important organization and insight into the topic (Batson et al., 1993; Bering \& Johnson, 2005; Hansen \& Norenzayan, 2006; Hood, Hill, \& Spilka, 2009; Hunsberger \& Jackson, 2005; Johnson \& Bering, 2006; Norenzayan \& Shariff, 2008). So, then why do we need another review? First, although the subject itself is not new, it never seems to get old. Studies on the effect of religion on prosociality are a favorite subject in the psychology of religion, and many studies have been conducted in the last few years. This constant stream of fresh findings makes the topic one that needs to be frequently examined and updated. Also, unlike other reviews of the subject, we do not argue any specific theoretical point of view. Rather, we (hope to) adopt a neutral point of view, and piece together the picture of religious prosociality from the evidence, by asking three basic questions: who helps, when do they help, and why do they help?

1. Who is prosocial? The first section of this chapter addresses the associations between individual religiosity and prosocial behavior. We find that differences in religiosity can increase prosociality, but it often depends on the kind of religious belief and the target of help.

2. When does religion increase prosociality? We review experimental studies demonstrating religious cues- such as picture of a Church, or priming religious concepts can increase prosocial behavior

3. Why would religion increase prosocial behavior? Although researchers agree that religion is connected to moral belief, the particular mechanisms underlying religious prosociality are hotly debated (cf. Graham \& Haidt, 2010; Shariff, Norenzayan, \& Henrich, 2009). We compare several such theories and their ability to account for the 
existing evidence reviewed in the previous sections. We find that religious prosociality may me created through a concert of different cognitive and social mechanisms that each contribute to prosocial motivation.

The goal of this chapter is to offer an analysis of the relationship between religion and prosociality. We hope to reveal a big picture of religious prosociality is that is complex, but it can be understood as an interaction between personal, cognitive, and social forces.

\section{WHO IS PROSOCIAL? INDIVIDUAL DIFFERENCES IN RELIGIOSITY}

Religious belief systems provide moral instruction for believers, whether through stories or in explicit laws. In this section, we investigate the question: who helps?

Are religious people more prosocial?

If religious followers internalize religious laws as their own moral values, we might expect that greater religiousness would be associated with greater prosociality. Self-report data suggests some support for these predictions. For example, religiosity and church attendance are associated with more volunteerism (Marris et al., 2000) and blood donations (St. John \& Fuchs, 2005). Across many different cultures and nationalities, belief in God and the afterlife predicts moral attitudes towards specific moral behavior, for example adultery or cheating on taxes. (Atkinson \& Bourrat, 2010). And there is at least some evidence that religiosity impacts prosocial behavior by internalized prosocial values. A meta-analysis of 21 samples drawn from 15 countries revealed a weak but positive association between religiosity (as a general trait) and the value of Benevolence, or concern for welfare of others (Saroglou, Delpierre, \& Dernelle, 
2004). In a self-report survey of adolescents, religiosity predicted the prosocial value of kindness, which in turn predicted willingness to help others, especially when the help was anonymous and altruistic (i.e. the primary goal is benefit others and not for self-gain) (Hardy \& Carlo, 2005).

Still, other evidence suggests that any associations between religiosity and prosociality are due to extraneous factors or is extrinsically motivated. For example, religiosity sometimes predicts helping only close others (e.g. friend or neighbor) but not unknown others, suggesting a primary concern for prosocial reputation within a group or welfare of the ingroup (Saroglou, et al., 2005). In some cases, the relationship between religion and prosocial behavior may be circumstantial or indirect: after the Oklahoma City bombing, religious people made more donations and gave more blood, but this may have been because of the Church's facilitation of these donations, rather than the religiosity of the givers (St. John \& Fuchs, 2005). Other data suggests that religion's apparent effect on prosocial behavior may be due confounding demographic factors: when race and gender are controlled for, the benevolent effect of religiosity disappears (Gillum \& Masters, 2010).

In sum, religion shows some positive effect on prosocial behavior, but these effects are not always straightforward. Below, we take a closer look at how, by differentiating ways of being religious, more clarity can be gained in the study of religion's influence on helping.

\section{Kinds of religious belief}

Correlational evidence suggests some relation between religion and prosociality. But often these studies overlook differences in the kind of religious belief different people hold - not differences of affiliation (such as being a Catholic or Protestant), but differences in the style of 
religious belief or the general approach to religion. One of the first studied individual differences in religiosity is that between intrinsic and extrinsic religious orientations (Allport, 1966; Allport \& Ross, 1967). Whereas intrinsically oriented believers view their religion as an end in itself (belief for its own sake), extrinsically oriented believers use religion as a means to gain other things, for example, social support from the group (Allport, 1966; Allport \& Ross, 1967). Several studies suggest people with a stronger intrinsic orientation may be more prosocial those with an extrinsic orientation people. Intrinsically oriented people have more salient goals of social reward (e.g. praise), which in turn predicts volunteer behavior (Batson \& Flory, 1990). Compared to extrinsically-oriented believers, intrinsically oriented people are more empathetic toward others (Watson et al., 1984), score higher on self-reported altruism (Chau et al., 1990), and are more charitable (Hunsberger \& Platonow, 1986). In addition, intrinsic orientation also better predicts non-spontaneous helping behavior such as a recurring and long term commitment to volunteering (Benson et al., 1980).

In addition to intrinsic and extrinsic religious orientations, Daniel Batson introduced a third orientation, quest religiosity (Batson, 1976). Believers with a quest orientation are focused on a search for existential meaning and an emphasis on questions over answers in the religious domain (Batson, 1976). Although both intrinsic and quest religiosity are associated with helping, researchers have found differences in how people with these orientations help others. For example, in a study of college students, intrinsically oriented participants reported more interest in volunteering, but quest oriented participants were more likely to join a volunteer service after graduation (Bernt, 1989). Quest-oriented people also prefer spontaneous forms of helping (e.g. helping someone pick up dropped papers), but intrinsically oriented people prefer non-spontaneous helping, such as volunteer work (Hansen, Vandenberg, \&Patterson, 1994). 
Compared with intrinsic religiosity, quest religiosity has been associated with a more empathetic, universal form of prosociality (e.g., Batson \& Gray, 1981). Those with an intrinsic orientation tend to offer help whether or not the target wants it; in contrast, those with a quest orientation offered a more tentative kind of help that did not persist if the target refused (Batson, 1976; see also Batson \& Gray, 1981). In addition, differences in intrinsic and quest religiosity are associated with differences in who one helps. Those with a quest orientation are also more likely to help others with beliefs and values that oppose their own, whereas intrinsic-oriented believers sometimes limit prosociality to likeminded others. For example, an intrinsic religious orientation is associated with reduced helping towards those who violate one's religious values (e.g., homosexuality), whereas a quest orientation is not (Batson, Floyd, Meyer, \& Winner, 1999; Batson, Eidelman, Higley, \& Russel, 2001; Batson, Denton, \& Vollmecke, 2008). Batson (1990) emphasizes that quest orientation is related to altruistic helping motivations (where the primary concern is for others), whereas intrinsic orientation is more strongly associated with egoistic helping motivations (primary concern for self or ingroup).

Overall, research on religious orientation supports the conclusion that one's motivations for being religious are related to both who and how one helps. However, intrinsic, extrinsic, and quest orientations are not the only individual difference in kind of religious belief. For example, religious fundamentalism - characterized by stronger religious conviction and concern with the moral authority of religion (Altemeyer \& Hunsberger, 1992)—is related to reduced helping towards perceived outgroups (Blogowska \& Saroglou, 2011), especially outgroups perceived as a moral threat (e.g., homosexuals and single mothers; Jackson \& Esses, 1997). Given that fundamentalism is often negatively related to quest religiosity (Batson et al., 2008; Goldfried \& Miner, 2002), these findings are consistent with the conclusion that quest oriented believers are 
more universally prosocial. However, other research suggests that the limited extent of religious prosociality may be a more general feature of religiosity not limited to orientation or fundamentalism. For instance, when people were asked how they would react in a series of hypothetical situations involving both close and unknown others who needed help; religiosity predicted helping towards ingroup but not outgroup members (Saroglou, Pichon, Trompette, Verschueren, \& Dernelle, 2005).

\section{Who helps? The Bottom Line}

Though some studies suggest that religious people help more than less religious people, this relationship is qualified by an understanding of individual differences in religion. Psychological variables, such as religious orientation and fundamentalism have a profound impact on prosocial behavior. Also interesting, different types of religious belief (e.g., religious orientation) show different patterns of prosocial behavior depending on the target of help - e.g. a moral outsider/ insider.

\section{WHEN DOES RELIGION HELP? SITUATIONAL AND EXPERIMENTAL FACTORS.}

Social psychologists are inherently interested in aspects of the situation that influence prosocial behavior. That is, in addition to measuring one's religious disposition and correlating it with some measure of prosocial behavior, researchers have also taken to manipulating whether or not people are thinking religious thoughts. Does merely having religion on the mind make people more likely to help others?

It is worth noting that the researchers who conducted one of the most classic studies on the relation between religion and prosocial behavior didn't think so. Following the logic of the 
parable of the Good Samaritan (Luke 10: 25-37), Darley and Batson (1973) reasoned that people who are thinking "religious and ethical" thoughts should be no more likely to stop and help a person in need than someone who is not thinking about religion. To test this prediction, Princeton seminary students were put in a situation similar the parable of the Good Samaritan. They were asked to travel to another building on campus to give a talk, and on the way passed by a shabbily dressed confederate on their way who coughed and groaned, and appeared to need help. The researchers manipulated two variables to assess their influence on helping behavior. First, some participants were told that they would be giving a short talk on the parable of the Good Samaritan itself (and thus had religion on their mind when they passed the groaning confederate) whereas other participants were told they would be giving a talk on a non-helping related topic. Second, some participants were asked to rush to the other building whereas others were not asked to rush. Participants who had religion on their mind were no more likely to stop and help the confederate. Rather, the other situational variable - time - had a huge impact: people who were in a hurry were significantly less likely to stop and help than people who were not in a hurry.

Although having religious thoughts on the mind did not influence helping behavior in this classic study, researchers have since used a variety of methods to activate religious concepts and measure their influence on prosocial behavior. For Christians, Sunday is set aside as a holy dayto attend Church and worship. If religion does in fact have some association with prosocial behavior, we might expect this effect to be particularly robust on Sundays after people have just attended a church service and religious (prosocial) norms are highly salient. Indeed, this so called "Sunday effect" hypothesis does have some support. In one study, people who regularly attended church were more likely than people who did not regularly attend church to respond to 
an appeal for prosocial behavior (by continuing to bid for a charitable cause), but only on Sundays (Malhotra, 2001). There was no difference between religious and non-religious participants on charitable bidding on the other six days of the week. In contrast to Darley and Batson's (1973) "Good Samaritan” study above, this finding suggests that situational factors that make religion more salient can have an important effect on prosocial behavior. But given these conflicting findings, it is clear that the effect of activating religious concept on prosocial behavior is not straightforward. Next we review more recent studies that have used a variety of methods to experimentally manipulate religious cognition.

\section{Experimental Manipulations of Religious Cognition}

\section{Prosocial Intentions}

As we have just seen, the relative salience of religious thoughts — as opposed to simply measuring one's religious disposition - plays an important role in understanding the relation between religion and prosocial behavior. Also important, however, is the precise kinds of religious thoughts that can be activated, as not all kinds of religious concepts may be associated with prosocial behavior (Preston, Ritter, \& Hernandez, 2010). Pichon, Boccato, and Saroglou (2007), for example, have found evidence that religious priming increases prosocial intentions, but the effect is moderated by the valence of religious prime words:positive religious words(e.g., bless, faith, baptism), facilitated prosocial intentions, but neutral religious words (e.g., monk, chapel, altar), did not. Participants were first subliminally primed with positive religious primes were more likely to take charity pamphlets (containing information about an organization that provides food for disadvantaged people) to distribute to their friends. In a second study, participants primed with positive religious words showed increased accessibility of pro-social 
concepts, suggesting that positive religious words are more associated with pro-social behaviors (Pichon et al., 2007).

In addition to understanding the kinds of religious primes associated with prosocial intentions, a second important feature to consider is the target of behavior. That is, it may not be reasonable to expect religious primes to elicit universal prosocial behavior, but rather only prosocial behavior toward specific persons or groups (Preston et al., 2010; Saroglou, 2006). Research by Pichon and Saroglou (2009) has used pictures to manipulate both the target and the religious context of prosocial behavior. Participants were presented with a picture of a homeless person or an illegal immigrant taken in front of a church or inside a gymnasium. Merely being exposed to the picture of the person-in-need in front of a church increased self-reported intention to help, but only for the homeless person, and not for the illegal immigrant, who was violating the law (Pichon \& Saroglou, 2009). Thus although religious primes are associated with increased prosociality, this is true only for some religious primes and only for some targets.

\section{Moral Hypocrisy}

In situations that offer the possibility of acting prosocially toward another person, it is not often the case that people don't know what they ought to do. The golden rule is clear: do unto others as you would have them do unto you. Yet people often fail to live up to this moral standard. This is a phenomenon known as moral hypocrisy (Batson, Kobrynowicz, Dinnerstein, Kampf, Wilson, 1997), and may help explain why activating religious concepts sometimes causes increased prosocial behavior. That is, perhaps activating religious concepts in people's mind increases the salience of moral standards and thus discourages people from engaging in moral hypocrisy. Carpenter and Marshall (2009) addressed this question. Participants were told they were responsible for assigning themselves and another participant to a positive consequence 
task (i.e., entered into a raffle to win \$30) or a neutral consequence task (i.e., no chance to win money). Participants could make this decision themselves or flip a coin to determine the assignment. A moral hypocrite, in this case, would admit that flipping the coin is the fair method to make the task assignment, but then assign themselves to the positive consequence task anyway (either by choosing not to flip the coin or flipping the coin until the desired outcome is obtained). Just before choosing the task assignments, however, half of the participants were asked to read a series of nine Bible verses whereas the other half were not asked to do so. Participants who read the Bible verses prior to making the task assignment behaved significantly less like moral hypocrites (i.e., were more likely to act in accordance with their moral values of fairness) — but only when they scored high on an intrinsic religiosity scale. In other words, the religious primes had no measurable effect on people who were not religious as an end-in-itself.

\section{Cooperation}

Cheating for the sake of selfish benefit — or free-riding — is a threat to any cooperative community. Given the theoretical emphasis placed on religion's cultural-evolutionary role in reducing free-riding and increasing cooperation (see Theoretical Perspectives section below), the effect of activating religious thoughts on people's willingness to engage in either mutually beneficial cooperation with others or to cheat at others' expense has been an active area of research. Some of the most common methods to measure this behavior in the lab are through economic games such as the dictator game and the prisoner's dilemma. Shariff and Norenzayan (2007) used the Dictator game, for example, to examine the influence of implicit religious primes on prosocial behavior. Each participant was given $\$ 10$ to distribute between themselves and another person, but just before making their decision some participants were primed with neutral words and others were primed with religious words (e.g., spirit, divine, God, sacred, prophet). 
Among all participants in an undergraduate student sample (Study 1), but only among theists in a wider community sample (Study 2), religious primes led to increased fairness in the distribution of the money relative to participants primed with neutral words. Further, a higher proportion of participants behaved selfishly (i.e., offered nothing) in the neutral prime condition than in the religious prime condition, whereas a higher proportion behaved fairly (i.e., offered exactly \$5) in the religious prime condition than in the control condition (Shariff \& Norenzayan, 2007). In a similar study, Ahmed and Salas (2011) primed participants with religious or neutral concepts immediately before they engaged in a dictator game and a prisoner's dilemma game with another player. Consistent with the results of Shariff and Norenzayan (2007), participants primed with religious concepts gave significantly more money to the other player in the dictator game (35\% vs. $27 \%$ ) and were significantly more likely to cooperate in the prisoner's dilemma (44\% vs. 27\%). Finally, Tan and Vogel (2008) manipulated whether or not participants were aware of the other players level of religiosity during an economic game. Results suggested that merely knowing that the other player was highly religious increased trust — especially for participants who were highly religious themselves (Tan \& Vogel, 2008).

\section{Decreased Anti-social Behavior}

Though the focus of this chapter is prosocial behavior, it is worth mentioning that religious priming can also decrease antisocial behavior such as cheating, presumably by activating feelings of being watched by a supernatural agent (Gervais \& Norenzayan, 2012) and/or a desire to avoid supernatural punishment (Johnson \& Bering, 2006). In one study, participants had the chance to cheat on a test of spatial reasoning by not dismissing answers that appeared on the computer screen before the questions (supposedly as part of a computer error; 
Bering, McLeod, \& Shackelford, 2005). Just before completing the test, some participants were told that the task was created in memory of a recently deceased graduate student, and the experimenter mentioned that she had recently seen the deceased students' ghost roaming the laboratory. Participants who were primed to think of a ghost pressed the spacebar significantly faster than participants who were not so primed. A similar effect has been observed in children. Piazza, Bering, and Ingram (2011) demonstrated that kids (ages 5-9) who were left alone in a room to complete a challenging task after being introduced to an invisible "Princess Alice" were significantly less likely to cheat—but only if they believed Princess Alice was real. Religious primes have also been shown to decrease anti-social attitudes toward out-groups. Ginges, Hansen, and Norenzayan (2009) found, for example, that Jewish Israeli settlers were significantly less likely to approve of suicide attacks against Palestinians if they were primed to think about how much they pray (6\% approval) relative to participants who were not primed with any religious concept (15\% approval). It is important to note, however, that participants primed to think of synagogue attendance at the beginning of the survey displayed the strongest approval of suicide attacks against Palestinians (23\%), suggesting that the effects of religious primes are not uniformly positive.

\section{Religiosity as a Moderator}

Experimental priming studies have shown that activating religious cognition can increase prosocial behavior and intentions in a wide variety of tasks. Many of these priming studies also measure individual religiousness, which might be expected to moderate the effects of experimental manipulations. But in practice, the effects of religiosity in experimental paradigms are mixed at best. Some studies do show an interaction between individual and experimental 
variables. Carpenter and Marshall (2009) found that when religiosity was primed, intrinsic religiosity predicted decreased moral hypocrisy. In the cooperation paradigm by Tan and Vogel (2008), participants cooperated with a partner who was known to be religious, especially if participants were religious themselves. Yet, other studies show mixed effects of religiousness, for example, Shariff and Norenzayan (2007) found in one study that religious primes increased giving in both religious and secular participants (Study 1), and in another study that the effect was found only in believers (Study 2). Still other studies show no effect of religiosity (e.g., Darley \& Batson, 1973; Ahmed \& Salas, 2011).

Other religious priming studies also show mixed effects of personal religiosity as a moderator (Laurin, Kay, \& Fitsimmons, 2012), suggesting that the atheist effect is not limited to prosociality. It is not clear why priming effects have worked well with non-believers, but one possibility is that the moral associations tied to religion are also activated in non-believers, because of cultural exposure and shared knowledge of religious values. But as we reviewed above, prosociality is best predicted by the specific kind of religious belief a person holds (e.g. religious orientation), and also the target of help. These important differences in belief are often overlooked in priming studies, but perhaps future research may show that priming effects also interact with the kind of religious belief (or disbelief) a person holds.

\section{When does religion increase prosociality? The Bottom Line}

Overall, increasing the salience of religious thoughts can both increase prosocial behavior and decrease antisocial behavior. However, the causal influence of religious primes on prosocial behavior is not entirely straightforward. What we do know is that the efficacy of religious priming can depend on several important factors: the kind of religious concept being activated, 
the target of the prosocial behavior, and one's religiosity. In the following section we examine different theoretical perspectives that have been advanced to explain the association between religion and prosociality.

\section{WHY DOES RELIGION INCREASE PROSOCIALITY? THEORETICAL PERSPECTIVES}

A variety of theoretical perspectives have been formulated to predict and explain a relationship between religion and prosociality. Most of these theories emphasize religion's ability to promote living in cooperative groups, but differ in the mechanisms they propose and in the scope of the prosocial behavior they predict. In this section, we discuss several such theories, beginning with the supernatural punishment hypothesis (e.g., Bering \& Johnson, 2005; Johnson \& Bering, 2006; Shariff, Norenzayan, \& Henrich, 2009), which argues that the felt presence of a watchful god is an adaptation that enables humans to live in large-scale cooperative groups. In contrast to the supernatural punishment hypothesis's emphasis on cheating behavior and cooperation, the moral communities perspective argues that religion's role in group cohesion stems from its emphasis on a broader, binding set of moral principles than only harm and fairness (Graham \& Haidt, 2010). The costly signaling theory holds that religiosity and its associated behavior communicate commitment to the ingroup and dedication to moral behavior (e.g., Irons, 1996; Irons, 2001; Sosis \& Alcorta, 2003). Finally, the self-regulation account holds that religion, through its beliefs, practices, and associated community, promotes prosociality by strengthening one's ability to monitor and adjust one's behavior (McCullough \& Willoughby, 2009). 


\section{Supernatural Punishment Hypothesis}

Imagine that you have just seen $\$ 20$ fall out of a stranger's pocket onto the sidewalk.

There is no one else around, and the stranger, completely unaware of the loss, is continuing to walk away. You bend over and pick up the cash. Do you keep it or give it back? Perhaps you are a moral person and would give it back no matter what, but there are no drawbacks in this situation for keeping the money. What if there was someone else around, and you knew that that person would not only see you steal the money but also punish you for doing so; would this make you (or anyone else) more likely to give the money back?

According to the supernatural punishment hypothesis, belief in God prevents antisocial behavior (i.e., stealing the \$20) and promotes prosocial behavior (i.e., returning the \$20) (Bering \& Johnson, 2005; Johnson \& Bering, 2006; Shariff et al., 2009). People living in large-scale societies face situations, like the opportunity to take the stranger's money, that allow for the anonymous and surreptitious violation of moral rules. When a group becomes too large or diffuse to keep track of who is good and who is bad, what keeps its members from benefitting from the cooperation of others while not contributing themselves? This is the role of god in the supernatural punishment hypothesis. If you know that God will see you pick up the money, that He will know if you do not really intend to returns it, and that He will punish you for stealing it, you might be more likely not to steal at all or even to return the money to the stranger. This is the central argument of the supernatural punishment hypothesis.

Critical to the supernatural punishment account is the amazing capacity of humans to reason about the minds of others (Premack \& Woodruff, 1978). This ability, called theory of mind, allows us to imagine the thoughts and intentions of other people, and is essential to social functioning. Belief in God makes use these mind-reading abilities, as applied to the mind of God 
(Johnson \& Bering, 2005; Shariff et al., 2009). For example, when you consider that God can see you take the $\$ 20$ that the stranger dropped, you are engaging in first-order theory of mindimagining the contents of someone else's mind. If you also think that God would be angry about this behavior, then the mind of God becomes a moral audience for your actions.

Evidence on support of the supernatural punishment hypothesis comes from studies that the (imagined) presence of a supernatural agent diminishes cheating (e.g., Bering et al., 2005; Piazza et al., 2011). In the "Princess Alice" study, for example, there was no difference in cheating between children who were observed by a human confederate and those who believed they were watched by the imaginary princess (Piazza et al, 2011). This provides evidence that representing the mind of supernatural being has similar effects to representing the mind of a human. However, it is not enough that supernatural punishment deters antisociality; it should also increase prosociality. The evidence from surveys suggests that this may be the case (Atkinson \& Bourrat, 2011; Johnson, 2005; Shariff \& Norenzayan, 2011), but experimental evidence would strengthen the causal inference that thinking about supernatural beings makes people more prosocial.

Despite the evidence amassed to support the supernatural punishment hypothesis, there is disagreement about how beliefs in such punishing agents arose. On the genetic adaptationist account (Bering \& Johnson, 2005), belief in such a deity was selected for as a genetic adaptation because it contributed to cooperative living in larger societies. Believing one's bad behavior is automatically detected and punished by an ever-watchful being prevents one from acting noncooperatively. According to Bering and Johnson (2005), someone who believes that a god knows his or her thoughts and behaviors has an evolutionary advantage over an individual who does not 
have such a belief. This advantage comes from the increased social vigilance of the first person. Someone who is constantly wary of his or her reputation will get along better with other group members and benefit more from their generosity and cooperation. In turn, if group members are concerned about this detection and punishment, the costs of enforcing cooperation are reduced and the group may transfer resources that would have been spent on punishing transgressors on productive and cooperative endeavors (Johnson \& Bering, 2006). Because of these advantages, belief in punishing supernatural beings has become an individual level genetic adaptation in humans.

Others argue that the genetic evolutionary model is not adequate because it is unclear if or how such beliefs could be genetically encoded and because such beliefs are not present in all societies (Shariff et al., 2009). Instead, the cultural adaptationist account argues that religion was a cultural innovation that adeptly increased cooperation in groups. Groups that developed beliefs in punishing supernatural agents, and successfully enforced commitment to them, were able to outcompete groups without such beliefs due to their increased cooperation and cohesion. Thus, religion was an adaptation of the group and not the individual. It became an adaptation through a process called gene-culture coevolution (Henrich \& McElreath, 2006). According to this model, religion is a cultural innovation that exploits biologically adapted cognitive mechanisms, such as theory of mind (Shariff et al., 2009). As groups espousing belief in punishing agents came to dominate, the adaptive cognitive mechanisms underlying this belief, such as theory of mind, necessarily became more common in the human genetic pool.

The current social psychological evidence does not favor one account of the supernatural punishment more than another, at least not definitively. More work will be needed to distinguish between the psychological mechanisms underlying the supernatural punishment effect. One 
proposed mechanism, increased self-awareness in the believed presence of supernatural agents, has received support in the form of research suggesting that God primes increase public self awareness and socially desirable responding, especially among believers (Gervais \& Norenzayan, 2012). However, no work has directly examined whether increased self-awareness meditates the effect of religious priming on prosociality. In addition, if Johnson and Bering (2006) are correct that belief in supernatural punishment is a genetic adaptation that prevents cheating even in anonymous situations, then one would expect to find that being tempted to cheat should make one feel watched. Since religious primes were probably not ubiquitous features of prehistorical environments, it is not enough to show that activating supernatural agent concepts prevents cheating. Instead, the desire to cheat should be quashed by its automatic activation of supernatural monitoring. So far, evidence on this is lacking, except perhaps for one study demonstrating that subliminal exposure to sin- or temptation-related words made participants faster in recognizing religious words in a lexical decision task (Fischbach, Friedman, \& Kruglanski, 2003). Despite the work that remains to be done, existing evidence suggests that belief in punishing supernatural agents is associated with greater cooperation.

\section{Self-Regulation}

McCullough and Willoughby (2009) agree that belief in supernatural agents promotes self-monitoring, however they suggest that it is the resulting self-regulation that ultimate mediates the associations between religion and prosociality. Perhaps what makes McCullough and Willoughby's (2009) account so interesting is its synthesis of existing literature and its consideration for the multiple facets of religion, from ritual practice to belief in the supernatural and from individual behavior to community. In doing so, they draw on research suggesting (1) that people scoring high in measures of self-control also score more highly on measures of 
religiosity (e.g., Bergin, Masters, \& Richards, 1987; French, Eisenberg, Vaughan, Purwono, \& Suryanti, 2008), (2) that the religious have children with greater self-control and less impulsiveness (e.g., Bartkowski, Xu, \& Levin, 2008), and (3) that religiosity is negatively associated with many risky behaviors, such as gambling (e.g., Baier \& Wright, 2001), and positively associated with many kinds of precautionary behaviors, such as higher age of first intercourse (e.g., Regnerus, 2007). They argue that religious communities act as moral audiences that constrain behavior and provide additional boosts to self-monitoring. Because religious settings are restrictive in terms of allowable behaviors, those who practice a religion will have more experience with self-monitoring. In addition, religious rituals, such as Buddhist meditation and Catholic confession, may serve as opportunities to increase self-regulatory control and to compare oneself to one's goals. McCullough and Willoughby additionally claim that goals positively related to self-regulation and prosociality (e.g., being polite) are promoted by religion and goals negatively related to self-regulation and prosociality (e.g., personal gratification) are inhibited by religion. By sanctifying these self-regulatory goals, religion establishes their importance relative to other goals.

\section{Moral Communities}

Rituals such as weddings, Communion, and baptism are vivid reminders of how religion brings people together for practice. Religion is fundamentally more than a set of beliefs in an individual's head; it is a community, a culture, a way of life. Graham and Haidt (2010) suggest that religion's contribution to group cohesion comes from its emphasis on what they call the “binding" moral foundations (p. 141). According to moral foundations theory (Haidt \& Graham, 2007), the three binding foundations form additional sources of moral concern to harm and 
fairness, the principles traditionally studied as comprising moral behavior (see Gilligan, 1982; Turiel, 1983). These foundations are ingroup/loyalty, which places moral value on respecting and acting favorably towards members of one's groups; authority/respect, which places moral value on following authority and respecting community leaders and parents; and purity/sanctity, which places moral value on avoiding disgusting behaviors and striving for moral and spiritual cleanliness. These foundations bind group members together by imbuing group members and group activities with symbolic value. Religion strengthens ingroup moral intuitions through teachings that emphasize a religious people or church that are worthy of loyalty and hold a special moral position relative to outgroup members. Respect for religious authority serves to bind groups together through shared beliefs and practices derived from common sources. Many of these beliefs and traditions may focus on matters of cleanliness, purity, and sacredness, such as ritual washing, that, when imparted with symbolism, bind people into belief groups.

Graham and Haidt (2010) argue that religious prosociality is not driven by belief in the supernatural; rather, it is the result of the sense of social support and bonding that occurs when a community collectively values the three binding foundations. They interpret findings that both religious and civic primes decrease cheating (Shariff \& Norenzayan, 2007) as evidence for the effect of a more general process of moral community building. Rather than supernatural observation, it is the emphasis of ingroup loyalty, respect for authority, and purity present in both religious and civic systems that makes individuals cooperative. Although this theory accords well with existing evidence (e.g., that religiosity is associated with social support; Koenig, et al., 1997), it is a relatively new contribution to the field that remains to be tested. 


\section{Costly Signaling}

Graham and Haidt (2010) are not the only theorists to suggest that community building is the primary advantage of religion. Sosis and Alcorta (2003; Alcorta \& Sosis, 2005) propose that participating in religion is a way of communicating commitment to one's group. Their argument relies on costly signaling theory (Bleige Bird \& Bird, 2001), which proposes that seemingly onerous behaviors can serve as signs of adaptive fitness to potential mates. When applied to humans, this means that some behaviors, such as altruism, might not benefit an individual in the short-term, but they have long-term benefits based on what they communicate to others. In the case of altruism, the initial cost of helping others without reward for the self is offset by an increase in reputation and the communication that one has desirable traits such as generosity and compassion (Gintis, Smith, \& Bowles, 2001). Participation in religion involves cooperative and ritual behavior that does not necessarily benefit an individual directly but instead increases his or her standing in the community and fosters trust among those who share the same practices.

According to Alcorta and Sosis (2005), religious rituals that evoke positive emotions, such as the joy of a wedding, create communal empathy and associate religious symbols with rewards. Such rewarding experiences increase an individual's likelihood of engaging in religious rituals in future and bind the individual to other community members. In contrast, religious rituals that evoke negative emotional experiences impose a cost to participation in religion that minimizes free-riding by making it easier to identify those whose commitment is not genuine. Consider the Catholic ritual of confession; the associated guilt and reparations entailed by confession impose a cost on participation in the Catholic faith. Participation in religious ritual thus constitutes a costly signal that one is committed to group cooperation. 
Support for this theory comes from historical and correlational research into the role of religion in community development and cooperation. Sosis and Bressler (2003) found that of 83 communes in $19^{\text {th }}$ century United States, those that were bound together by religious principles were less likely to come to an end due to economic failure or internal disputes, suggesting that they were better able to solve collective action problems. When Sosis and Ruffle (2003) asked Israelis living in communes (kibbutzim) to participate in an anonymous economic game, men living in religious communes cooperated more than women living in religious communes and more than both men and women living in secular communes. They argue that the difference between men and women living in religious communes may be due to the fact that men in these communes participate more frequently in collective rituals and collective ritual participation is what drives increased cooperation.

Why does religion affect prosociality? The Bottom Line

Many different theories predict that religious belief shapes prosocial behavior. But there is probably is no single explanation that best predicts religious prosociality, nor is it necessary to try to find one. Instead, the link between religion and prosociality likely arises from a number of cognitive and social mechanisms. Connections to cognitive factors, such as fear of supernatural punishment from gods that are a constant moral audience, (Bering \& Johnson, 2005; Shariff, Norenzayan, \& Henrich, 2009), can increase self-regulation that is needed for prosociality. Other social influences shape motivations to be prosocial, such as a sense of shared group identity and morality of the group (Graham \& Haidt, 2010). Religious communities serve as ingroups that define and enforce moral rules, promote reciprocity, and reward participation in costly prosocial and ritual behavior (Alcorta \& Sosis, 2005). These different forces each shape 
prosocial behavior by different routes, but all demonstrate the close association between morality and religion.

\section{SUMMARY}

Connection between religion and prosocial behavior is predicted by many scholars, but an analysis of the research literature reveals a somewhat complex picture of religious prosociality. We see that there are general effects of religiosity in prosocial attitudes and charitable giving, but it is not known if these results due to extraneous social factors. Furthermore, certain types or styles of religiosity (such as quest/ intrinsic orientations) were stronger predictors of prosociality, depending on the context and target of help. We also reviewed evidence from a wide variety of studies that religious cognition can increase prosocial behavior, (e.g., cooperation, sharing, and giving). These studies often use priming techniques to activate religious cognition, and though it is not entirely certain what kind of "religious cognition" is activated (i.e., the religious constructs being activated by words such as "God" or "church"), the preponderance of positive findings suggest that these concepts are tightly connected to prosocial concerns.

An interesting point is that experimental priming effects often show effects with selfreported atheists, as well as believers (Shariff \& Norenzayan, 2007; Ahmed \& Salas, 2011). We might expect these effects only relevant to believers, as atheists actively reject the concept of the God and/ or institutional religion. It also seems inconsistent with correlational evidence that religiosity increases prosociality. Currently, there no accepted explanation for the atheist effect in religious priming studies. One possibility is that atheists share the same associations between religion and morality as believers, because of a shared cultural experience with religion. If so, 
religious concepts should activate prosocial goals in both atheists and believers. This would speak to the deep connection between religion and morality, that these primed associations are held by people who consciously reject the beliefs.

Finally, we discussed several different theoretical accounts that predict religious prosociality, but differ in their emphasis of cognitive (Being \& Johnson, 2005; McCullough \& Willoughby, 2009) and social mechanisms (Sosis\& Alcorta, 2003; Graham \& Haidt, 2010). But we see no reason why different theories are incompatible. Religion is a broad social institution, that touches on moral, institutional, personal and interpersonal aspects of life, and so we should expect that different aspects of religious belief influences prosociality by different mechanisms.

\section{Conclusion}

The picture of religious prosociality is rich and complex, and at first glance may seem to be too unclear to understand. But taking a step back, some things come into focus. Religion is interwoven with many different domains of life: personal, family, and institutional components and influences religion by personal, cognitive, and social forces. The multitude of connections between prosociality and religion in by different forces demonstrates the importance of morality as a dominant theme that pervades numerous domains of religious belief and practice. 


\section{REFERENCES}

Ahmed, A. M. \& Salas, O. (2011). Implicit influences of Christian religious representations on dictator and prisoner's dilemma game decisions. The Journal of Socio-Economics, 40, $242-246$.

Alcorta, C. S., \& Sosis, R. (2005). Ritual, emotion, and sacred symbols. Human Nature, 16, $323-$ 359.

Allport, G. W. (1966). Religious context of prejudice. Journal for the Scientific Study of Religion, 5, 447-457.

Allport, G., \& Ross, J. M. (1967). Personal religious orientation and prejudice. Journal of Personality and Social Psychology, 5, 432-443.

Altemeyer, B., \& Hunsberger, B. (1992). Authoritarianism, religious fundamentalism, quest, and prejudice. The International Journal for the Psychology of Religion, 2, 113-133.

Atkinson, Q. D., \& Bourrat, P. (2011). Beliefs about God, the afterlife and morality support the role of supernatural policing in human cooperation. Evolution and Human Behavior, 32, $41-49$.

Baier, C., \& Wright, B. R. E. (2001). "If you love me, keep my command- ments": A metaanalysis of the effect of religion on crime. Journal of Research in Crime and Delinquency, 38, 3-21.

Bartkowski, J. P., Xu, X., \& Levin, M. L. (2008). Religion and child development: Evidence from the early childhood longitudinal study. Social Science Research, 37, 18-36.

Batson, C. D. (1990). Good Samaritans- or priests and Levites? Using William James as a guide in the study of religious prosocial motivation. Personality and Social Psychology Bulletin, 16, 758-768. 
Batson, C. D. (1976). Religion as prosocial: Agent or double agent? Journal for the Scientific Study of Religion.

Batson, C. D., Denton, D. M., \& Vollmecke, J. T. (2008). Quest religion, anti-fundamentalism, and limited versus universal compassion. Journal for the Scientific Study of Religion, 47, $135-145$.

Batson, C. D., Eidelman, S. H., Higley, S. L., \& Russell, S. H. (2001). “And who is my neighbor?" II: Quest religion as a source of universal compassion. Journal for the Scientific Study of Religion, 40, 39-50.

Batson, C. D., \& Flory, J. D. (1990). Goal-relevant cognitions with helping by individuals high on intrinsic, end religion. Journal for the Scientific Study of Religion, 29, 346-360.

Batson, C. D., Floyd, R. B., Meyer, J. M., \& Winner, A. L. (1999). “And who is my neighbor?:” Intrinsic religion as a source of universal compassion. Journal for the Scientific Study of Religion, 38, 445-457.

Batson, C. D., \& Gray, R. A. (1981). Religious orientation and helping behavior: Responding to one's own or to the victim's needs. Journal of Personality and Social Psychology, 40, $511-520$.

Batson, C. D., Kobrynowicz, D., Dinnerstein, J. L., Kampf, H. C., Wilson, A. D. (1997). In a very different voice: Unmasking moral hypocrisy. Journal of Personality and Social Psychology, 72, 1335-1348.

Batson, C.D., Schoenrade, P., Ventis, W.L. (1993). Religion and the Individual: A SocialPsychological Perspective. New York: Oxford University Press. 
Benson, P.L., Dehority, J., Garman, L., Hanson, E., Hochschwender, M., Lebold, C., Rohr, R., \& Sullivan, J.(1980). Intrapersonal correlates on fonspontaneous helping behavior. The Journal of Social Psychology, 110, 87-95.

Bergin, A. E., Masters, K. S., \& Richards, P. S. (1987). Religiousness and mental health reconsidered: A study of an intrinsically religious sample. Journal of Counseling Psychology, 34, 197-204.

Bering, J. M., \& Johnson, D. (2005). “ O Lord You perceive my thoughts from afar”:

Recursiveness and the evolution of supernatural agency. Journal of Cognition and Culture, 1, 118-142.

Bering, J. M., McLeod, K., \& Shackelford, T. K. (2005). Reasoning about dead agents reveals possible adaptive trends. Human Nature, 16, 360-381.

Bernt, F. M. (1989). Being religious and being altruistic: A study of college service volunteers. Personality and Individual Differences, 10, 663-669.

Blogowska, J., \& Saroglou, V. (2011). Religious fundamentalism and limited prosociality as a function of the target. Journal for the Scientific Study of Religion, 50, 44-60.

Boyer, P. (2001). Religion Explained. London: William Heinneman.

Bushman, B. J., Ridge, R. D., Das, E., Key, C. W., \& Busath, G. W. (2007). When god sanctions killing: Effect of scriptural violence on aggression. Psychological Science, 18, 204-207.

Carpenter, T. P., \& Marshall, M. A. (2009). An examination of religious priming and intrinsic religious motivation in the moral hypocrisy paradigm. Journal for the Scientific Study of Religion, 48, 386-393. 
Chau, L. L., Johnson, R. C., Bowers, J. K., Darvill, T. J., \& Danko, G. P. (1990). Intrinsic and Extrinsic religiosity as related to conscience, adjustment, and altruism. Personality and Individual Differences, 11, 397-400.

Darley, J. M., \& Batson, C. D. (1973). "From Jerusalem to Jericho": A study of situational and dispositional variables in helping behavior. Journal of Personality and Social Psychology, 27, 100-108.

Fishbach, A., Friedman, R. S., \& Kruglanski, A. W. (2003). Leading us not into temptation: Momentary allurements elicit overriding goal activation. Journal of Personality and Social Psychology, 84, 296-309.

French, D. C., Eisenberg, N., Vaughan, J., Purwono, U., \& Suryanti, T. A. (2008). Religious involvement and the social competence and adjustment of Indonesian Muslim adolescents. Developmental Psychology, 44, 597- 611.

Gervais, W. M., \& Norenzayan, A. (2012). Like a camera in the sky? Thinking about God increases public self-awareness and socially desirable responding. Journal of Experimental Social Psychology, 48, 298-302.

Gillum, F. R. \& Masters, K. S. (2010). Religiousness and blood donation: Findings from a national survey. Journal of Health Psychology, 15, 163-172.

Ginges, J., Hansen, I., \& Norenzayan, A. (2009). Religion and support for suicide attacks. Psychological Science, 20, 224-230.

Goldfried, J. and M. Miner. 2002. Quest religion and the problem of limited compassion. Journal for the Scientific Study of Religion, 41, 685-95.

Graham, J., \& Haidt, J. (2010). Beyond beliefs: religions bind individuals into moral communities. Personality and Social Psychology Review, 14, 140-150. 
Haidt, J., \& Graham, J. (2007). When morality opposes justice: Conservatives have moral intuitions that liberals may not recognize. Social Justice Research, 20, 98-116.

Hansen, D. E., Vandenberg, B. \& Patterson, M. J. (1995). The effects of religious orientation on spontaneous and nonspontaneous helping behaviors. Personality and Individual Differences, 19, 101-104.

Hardy, S. A., \& Carlo, G. (2005). Religiosity and prosocial behaviors in adolescence: the mediating role of prosocial values. Journal of Moral Education, 34, 231-249.

Henrich, J., \& McElreath, R. (2006). Dual inheritance theory: The evolution of human cultural capacities and cultural evolution. In R. Dunbar \& L. Barrett (Eds.), Oxford handbook of evolutionary psychology (pp. 555-570). Oxford, UK: Oxford University Press.

Hunsberger, B., \& Jackson, L. M. (2005). Religion, meaning, and prejudice. Journal of Social Issues, 61, 807-826.

Hunsberger, B. \& Platonow, E. (1986). Religion and helping charitable causes. Journal of Psychology, 120, 517-528.

Irons, W. (1996). In our own self image: The evolution of morality, deception, and religion. Skeptic, 4, 50-61.

Irons, W. (2001). Religion as a hard-to-fake sign of commitment. In R. Nesse (Ed.), Evolution and the capacity for commitment (pp. 292-309). New York: Russell Sage Foundation.

Jackson, L. M. \& Esses, V. M. (1997). Of scripture and ascription: The relation between religious fundamentalism and intergroup helping. Personality and Social Psychology Bulletin, 23, 893-906.

Johnson, D. D. P. (2005). God's punishment and public goods. Human Nature, 16, 410-446. 
Johnson, D. D. P., \& Bering, J. M. (2006). Hand of god, mind of man: Punishment and cognition in the evolution of cooperation. Evolutionary Psychology, 4, 219-233.

Laurin, K., Kay., A. C., \& Fitzsimons, G. M. (in press). Divergent effects of activating thoughts of god on self-regulation. Journal of Personality and Social Psychology.

Marris, J. S., Jagers, R. J.,. Hatcher, C. A., Lawhon, G. D, Murphy, E. J., \& Murray, Y. F. (2000). Religiosity, volunteerism, and community involvement among African American men: An exploratory analysis. Journal of Community Psychology, 28, 391-406.

Malhotra, D. (2010). (When) are religious people nicer? Religious salience and the "Sunday Effect" on pro-social behavior. Judgment and Decision Making, 5, 138-143.

McCullough, M. E., \& Willoughby, B. L. B. (2009). Religion, self-regulation, and self-control: Associations, explanations, and implications. Psychological Bulletin, 135, 69-93.

Norenzayan, A., \& Shariff, A. F. (2008). The origin and evolution of religious prosociality.

Science, 322, 58-62.

Piazza, J., Bering, J. M., \& Ingram, G. (2011). "Princess Alice is watching you”: Children’s belief in an invisible person inhibits cheating. Journal of Experimental Child Psychology, 109, 311-320.

Pichon, I., Boccato, G., \& Saroglou, V. (2007). Nonconscious influences of religion on prosociality: A priming study. European Journal of Social Psychology, 37, 1032-1045.

Pichon, I., \& Saroglou, V. (2009). Religion and helping: Impact of target, thinking styles and just-world beliefs. Archive for the Psychology of Religion, 31, 215-236.

Randolph-Seng, B., \& Nielsen, M. E. (2007). Honesty: One effect of primed religious representations. The International Journal for the Psychology of Religion, 17, 303-315. 
Regnerus, M. D. (2007). Forbidden fruit: Sex and religion in the lives of American teenagers. New York: Oxford University Press.

Saroglou, V. (2006). Religion's role in prosocial behavior: Myth or reality? Psychology of Religion Newsletter, 31, 1-8.

Saroglou, V., Corneille, O., \& Van Cappellen, P. (2009). "Speak, lord, your servant is listening": Religious priming activates submissive thoughts and behaviors. International Journal for the Psychology of Religion, 19, 143-154.

Saroglou, V., Delpierre, V., \& Dernelle, R. (2004). Values and religiosity: a meta-analysis of studies using Schwartz's model. Personality and Individual Differences, 37, 721-734.

Saroglou, V., \& Galand, P. (2004). Identities, values, and religion: A study among Muslim, other immigrant, and native Belgian young adults after the 9/11 attacks. Identity, 4, 97-132.

Saroglou, V., Pichon, I., Trompette, L., Verschueren, M., \& Dernelle, R. (2005). Prosocial behavior and religion: New evidence based on projective measures and peer ratings. Journal for the Scientific Study of Religion, 44, 323-348.

Schwartz, S. H., \& Huismans, S. (1995). Value priorities and religiosity in four western religions. Social Psychology Quarterly, 58, 88-107.

Shariff, A. F., \& Norenzayan, A. (2011). Mean Gods Make Good People: Different Views of God Predict Cheating Behavior. International Journal for the Psychology of Religion, 21, $85-96$.

Shariff, A. F., \& Norenzayan, A. (2007). God is watching you: Priming god concepts increases prosocial behavior in an anonymous economic game. Psychological Science, 18, 803809. 
Shariff, A. F., Norenzayan, A., \& Henrich, J. (2009). The birth of high gods: How the cultural evolution of supernatural policing agents influenced the emergence of complex, cooperative human societies, paving the way for civilization. In M. Schaller, A. Norenzayan, S. J. Heine, T. Yamagishi, \& T. Kameda (Eds.), Evolution, Culture, and the Human Mind (pp. 119-136). New York: Psychology Press.

Sosis, R., \& Alcorta, C. (2003). Signaling, solidarity, and the sacred: The evolution of religious behavior. Evolutionary Anthropology: Issues, News, and Reviews, 12, 264-274.

Sosis, R., \& Bressler, E. R. (2003). Cooperation and commune longevity: A test of the costly signaling theory of religion. Cross-Cultural Research, 37, 211.

Sosis, R., \& Ruffle, B. J. (2003). Religious Ritual and Cooperation: Testing for a Relationship on Israeli Religious and Secular Kibbutzim. Current Anthropology, 44(5), 713-722.

St. John., C \& Fuchs, J. (2005). The heartland responds to terror: Volunteering after the bombing of the Murrah Federal Building. Social Science Quarterly, 83, 397- 415.

Tan, J. H. W., \& Vogel, C. (2008). Religion and trust: An experimental study. Journal of Economic Psychology, 29, 832-848.

Watson. P. J., Hood, R. W., Morris, R. J., \& Hall, J. R. (1984). Empathy, religious orientation, and social desirability. The Journal of Psychology, 117, 211-216. 